\title{
Bromine, iodine and sodium in surface snow along the 2013 Talos Dome-GV7 traverse (northern Victoria Land, East Antarctica)
}

\author{
Niccolò Maffezzoli ${ }^{1}$, Andrea Spolaor ${ }^{2,3}$, Carlo Barbante $^{2,3}$, Michele Bertò $^{3}$, Massimo Frezzotti ${ }^{4}$, and Paul Vallelonga ${ }^{1}$ \\ ${ }^{1}$ Centre for Ice and Climate, Niels Bohr Institute, University of Copenhagen, Juliane Maries Vej 30, 2100 Copenhagen $\varnothing$, \\ Denmark \\ ${ }^{2}$ Institute for the Dynamics of Environmental Processes, IDPA-CNR, Via Torino 155, 30170 Mestre, Venice, Italy \\ ${ }^{3}$ Ca' Foscari University of Venice, Department of Environmental Science, Informatics and Statistics, Via Torino 155 , \\ 30170 Mestre, Venice, Italy \\ ${ }^{4}$ ENEA, SP. Anguillarese 301, 00123 Rome, Italy \\ Correspondence to: Niccolò Maffezzoli (maffe@nbi.ku.dk)
}

Received: 30 September 2016 - Discussion started: 17 October 2016

Revised: 8 February 2017 - Accepted: 9 February 2017 - Published: 17 March 2017

\begin{abstract}
Halogen chemistry in the polar regions occurs through the release of halogen elements from different sources. Bromine is primarily emitted from sea salt aerosols and other saline condensed phases associated with sea ice surfaces, while iodine is affected by the release of organic compounds from algae colonies living within the sea ice environment. Measurements of halogen species in polar snow samples are limited to a few sites although there is some evidence that they are related to sea ice extent. We examine here total bromine, iodine and sodium concentrations in a series of $2 \mathrm{~m}$ cores collected during a traverse from Talos Dome $\left(72^{\circ} 48^{\prime} \mathrm{S}, 159^{\circ} 06^{\prime} \mathrm{E}\right)$ to $\mathrm{GV7}\left(70^{\circ} 41^{\prime} \mathrm{S}, 158^{\circ} 51^{\prime} \mathrm{E}\right)$ analyzed by inductively coupled plasma-sector field mass spectrometry (ICP-SFMS) at a resolution of $5 \mathrm{~cm}$.

We find a distinct seasonality of the bromine enrichment signal in most of the cores, with maxima during the austral spring. Iodine shows average concentrations of $0.04 \mathrm{ppb}$ with little variability. No distinct seasonality is found for iodine and sodium.

The transect reveals homogeneous air-to-snow fluxes for the three chemical species along the transect due to competing effects of air masses originating from the Ross Sea and the Southern Ocean.
\end{abstract}

\section{Introduction}

Halogen elements play an important role in polar boundary layer chemistry. The release of reactive halogen species from sea ice substrates has been demonstrated to be crucial in the destruction of tropospheric ozone at polar latitudes (socalled Ozone Depletion Events) during springtime (Barrie et al., 1988; Simpson et al., 2007; Abbatt et al., 2012).

Although the ocean is the main reservoir of sea salts, various condensed phases of high salinity are found on young sea ice surfaces. During seawater freezing, brine is separated from the frozen water matrix and expulsion processes lead to both upward and downward movement as temperature decreases (Abbatt et al., 2012).

Therefore, high salinity brine, frost flowers and salty blowing snow make newly formed sea ice surfaces a highly efficient substrate for inorganic halides and for their activation and release in the atmosphere (Saiz-Lopez et al., 2012b; Yang et al., 2008). Some studies have also pointed out the role of open water sea salts as a significant bromine source (Yang et al., 2005; Sander et al., 2003).

Reactive halogen species are involved in cyclic reactions between halogen radicals, their oxides and ozone. Reactions (R1)-(R3) show the main cycles for bromine. Atomic bromine radicals result from photolysis of molecular bromine, leading to formation of bromine monoxide, $\mathrm{BrO}$, through the reaction with ozone:

$$
\begin{aligned}
& \mathrm{Br}_{2} \rightarrow 2 \mathrm{Br}, \\
& \mathrm{Br}+\mathrm{O}_{3} \rightarrow \mathrm{BrO}+\mathrm{O}_{2}, \\
& \mathrm{BrO}+\mathrm{BrO} \rightarrow \mathrm{Br}+\mathrm{Br}+\mathrm{O}_{2} .
\end{aligned}
$$


Self-reaction of BrO may form two bromine atoms $(85 \%)$ or a $\mathrm{Br}_{2}$ molecule $(15 \%)$ which is readily photolyzed. The mechanism has a catalytic behavior that destroys ozone.

High concentrations of vertical columns of $\mathrm{BrO}$ and IO have been confirmed by SCIAMACHY (SCanning Imaging Absorption spectroMeter for Atmospheric CHartographY) satellite observations over Antarctic sea ice (Schönhardt et al., 2012).

Bromine can then be recycled and re-emitted from halogen-rich condensed phases (such as sea salt aerosol or other saline solutions) or from sea ice surfaces (Pratt et al., 2013), leading to an exponential increase of bromine in the gas phase (Vogt et al., 1996). Such reactions, known as bromine explosions, lead to enhanced bromine in the atmosphere. A recent 1-D chemistry model simulation predicted an increase of bromine deposition on surface snowpack after 24 to $48 \mathrm{~h}$ of recycling over first-year sea ice (Spolaor et al., 2016b).

The stability of bromine in the snowpack was investigated at Summit station, Greenland (Thomas et al., 2011), to explain the observed mixing ratios of $\mathrm{BrO}$. Measurements in East Antarctica (Legrand et al., 2016) revealed that snowpack cannot account for the observed gas-phase inorganic bromine in the atmosphere.

Bromine enrichment in snow (compared to sodium, relative to seawater) has therefore been recently used to reconstruct sea ice variability from ice cores both in the Antarctic and Arctic regions (Spolaor et al., 2013a, 2016b).

Iodine is emitted by ocean biological colonies and sea ice algae (Saiz-Lopez et al., 2012a; Atkinson et al., 2012) mainly in the form of organic alkyl iodide (R-I) and possibly other compounds. These can be released by wind-forced sea spray generation or percolation up to the sea ice surface through brine channels and are subsequently photolyzed to inorganic species. Plumes of enhanced IO concentrations from satellites and ground-based measurements were observed over Antarctic coasts, suggesting a link with biological and chemical sea ice related processes (Schönhardt et al., 2008). Grilli et al. (2013) have shown that ground-based IO concentrations in Dumont d'Urville (Indian sector) were more than one order of magnitude lower than in the Atlantic sector (Halley station, Saiz-Lopez et al., 2007), consistent with greater sea ice in the latter. On the other hand, only sporadic events with IO concentrations above detection limits have been observed in the Arctic regions, possibly due to the greater thickness and lower porosity of Arctic sea ice which prevents an efficient release of iodine species in the atmosphere (Mahajan et al., 2010).

Measurements of sea ice related species such as bromine and iodine could therefore allow a sea ice signature to be obtained from ice core records. Until recently, only sodium has been used to qualitatively reconstruct sea ice at glacialinterglacial timescales (e.g., Wolff et al., 2006), but this proxy has limitations at annual and decadal scales, because of the noise input caused by meteorology and open water sources (Abram et al., 2013). Methane sulfonic acid (MSA) is an end product of the oxidation of dimethylsulfide (DMS), which is produced by phytoplankton synthesis of DMSP (dimethylsulfonium propionate). MSA deposition has been successfully linked to Antarctic winter sea ice extent (Curran et al., 2003; Abram et al., 2010) and Arctic sea ice conditions (Maselli et al., 2017) on decadal to centennial scales, although some studies reported that the correlation with satellite sea ice observations is strongly site dependent (Abram et al., 2013). Several atmospheric studies reported no evidence of such link (Preunkert et al., 2007; Weller et al., 2011). Postdepositional processes causing loss and migration in the ice layers have also been widely reported to affect MSA, especially at low accumulation sites (Mulvaney et al., 1992; Pasteur and Mulvaney, 2000; Delmas et al., 2003; Weller et al., 2004; Isaksson et al., 2005; Abram et al., 2008).

Victoria Land has been intensively studied for the past two decades. The Taylor Dome (Grootes et al., 2001) and Talos Dome (Stenni et al., 2011) deep ice cores respectively provide 150 and $300 \mathrm{kyr}$ climatic records directly influenced by marine air masses. Sala et al. (2008) pointed out the presence of marine compounds (ikaite) at Talos Dome, typically formed at the early stages of sea ice formation. Their back trajectory calculations also showed that favorable events for air mass advection from the sea ice surface to Talos Dome are rare but likely to occur. An extensive study by Scarchilli et al. (2011) on provenance of air masses has shown that Talos Dome receives $50 \%$ of its total precipitation from the west (Indian Ocean), 30\% from the east (Ross Sea and Pacific Ocean) and approximately $15 \%$ from the interior. Within the framework of the ITASE program (International TransAntarctic Scientific Expedition, Mayewski et al., 2005), several traverses were carried out to evaluate the spatial patterns of isotopic values and chemical species linked to marine influence (Magand et al., 2004; Proposito et al., 2002; Becagli et al., 2004b, 2005; Benassai et al., 2005).

We present here bromine, iodine and sodium deposition in coastal East Antarctica by investigating their total concentrations within a series of shallow firn cores, covering the 2010-2013 time period. The cores were drilled during a traverse performed in late December 2013 in Victoria Land (East Antarctica) from Talos Dome $\left(72^{\circ} 48^{\prime} \mathrm{S}, 159^{\circ} 06^{\prime} \mathrm{E}\right)$ to GV7 $\left(70^{\circ} 41^{\prime} \mathrm{S}, 158^{\circ} 51^{\prime} \mathrm{E}\right)$. The variability of these species at sub-annual timescales will inform on timing and seasonality as well as spatial patterns of their deposition and possible depositional or postdepositional effects. Such information is necessary for the interpretation at longer timescales of these elements. These sub-annual resolution investigations are still limited to the Indian Ocean sector (Law Dome - Spolaor et al., 2014) of Antarctica. The only data available on iodine in the Atlantic sector (Neumayer station) have been reported from a snow pit study by Frieß et al. (2010). This study will test the regional variability of these tracers, providing measurements from the Ross Sea to the Indian Ocean sector that remains otherwise unstudied. 


\section{Sampling and analyses}

\subsection{Traverse sampling}

The traverse was performed in the northern Victoria Land region of East Antarctica (Fig. 1) from 20 November 2013 to 8 January 2014 . The starting and ending locations were Talos Dome ( $72^{\circ} 48^{\prime} \mathrm{S}, 159^{\circ} 12^{\prime} \mathrm{E}$ ) and location “6” (see Fig. 1), close to $\mathrm{GV7}\left(70^{\circ} 41^{\prime} \mathrm{S}, 158^{\circ} 51^{\prime} \mathrm{E}\right)$, for a total distance of about $300 \mathrm{~km}$. Talos Dome (275 km WNW from Mario Zucchelli station) is located approximately $250 \mathrm{~km}$ from the Ross Sea and $290 \mathrm{~km}$ from the Indian Ocean. GV7 is a peripheral site on the ice divide coming from Talos Dome, located just $95 \mathrm{~km}$ from the Indian Ocean.

During the transect, seven shallow cores, labeled hereafter TD (Talos Dome), 10, 9, GV7, 8, 7 and 6 were hand drilled to $2 \mathrm{~m}$ depth (except for GV7 which was $2.5 \mathrm{~m}$ ). The main characteristics of the coring sites are reported in Table 1. Density profiles were obtained from each core immediately after drilling.

The hand auger had a diameter of $10 \mathrm{~cm}$ and consisted of an aluminum barrel equipped with fiberglass extensions. The cores were sampled in the cold laboratory at the Cà Foscari University of Venice under a class 100 laminar flow hood. Each core was cut with a commercial hand saw and decontaminated through mechanical chiseling by removing approximately $1 \mathrm{~cm}$ of the external layer. Every tool was cleaned each time a piece of sample was decontaminated into three serial baths of ultra-pure water (UPW), which was changed every 10 washes. The cores were then subsampled at $5 \mathrm{~m}$ resolution ( $3 \mathrm{~cm}$ for the $\mathrm{GV7}$ core) into polyethylene vials previously cleaned with UPW and then kept frozen at $-20^{\circ} \mathrm{C}$ until analysis.

\subsection{Analytical measurements}

Total sodium (Na), bromine ( $\mathrm{Br})$ and iodine (I) concentrations were determined by inductively coupled plasma-sector field mass spectrometry (ICP-SFMS Element2, ThermoFischer, Bremen, Germany) at the Cà Foscari University of Venice following the methodology described in Spolaor et al. (2014).

The samples were melted one hour before measurements. During this time, exposure from direct light was reduced by covering them with aluminum foils, minimizing bromine and iodine photolysis reactions.

The introduction system consisted of a cyclonic Peltiercooled spray chamber (ESI, Omaha, USA). The operational flow rate was kept at $0.4 \mathrm{~mL} \mathrm{~min}^{-1}$, for an overall sample volume of $5.0 \mathrm{~mL}$. Each sample determination consisted of five instrumental detections (less than $2 \%$ variation between them). The five values were then averaged to provide the final quantification.

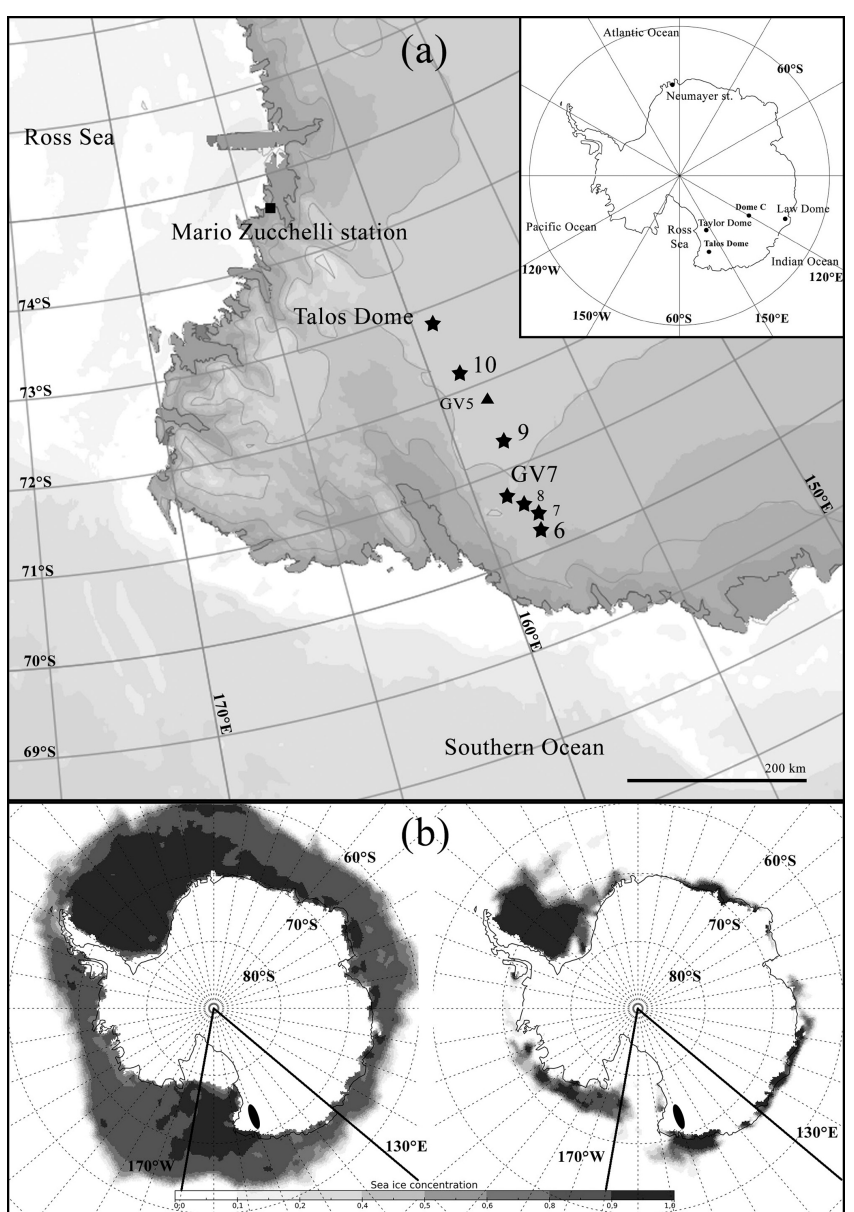

Figure 1. (a) Schematic map of the traverse area and coring sites marked with stars. The cores were drilled between 20 November 2013 and 8 January 2014 (early austral summer). (b) Maximum (left, August 2011) and minimum (right, January 2010) sea ice concentrations in the $130^{\circ} \mathrm{E}-170^{\circ} \mathrm{W}$ sector for the 2010-2013 time interval covered by the core records (NSIDC data from Meier et al., 2013). The traverse location is marked with an ellipse.

Each analytical run (10 samples) ended with a $\mathrm{HNO}_{3}$ (5\%) and UPW cleaning session of 3 min to ensure a stable background level throughout the analysis.

The external standards that were used to calibrate the analytes were prepared by gravimetric method by diluting the separate stock $1000 \mathrm{ppm}$ IC (Ion Chromatography) solution (TraceCERT ${ }^{\circledR}$ purity grade, Sigma-Aldrich, MO, USA) of the three analytes into a primary solution which was further diluted into six bromine and iodine standards $(0.01,0.05,0.1$, $0.5,1$ and $4 \mathrm{ppb})$ and 6 sodium standards $(0.5,1,5,10,50$ and $100 \mathrm{ppb})$.

The calibration regression lines showed correlation coefficients $R^{2}>0.99(N=6, p=0.05)$. The detection limits, calculated as three times the standard deviation of the blanks, were 50 and $5 \mathrm{ppt}$ for bromine and iodine respectively and $0.8 \mathrm{ppb}$ for sodium. The reproducibility of the measure- 
Table 1. Core drilling site information.

\begin{tabular}{lccccccc}
\hline Core site & $\begin{array}{c}\text { Core depth } \\
(\mathrm{cm})\end{array}$ & $\begin{array}{c}\text { Lat. } \\
(\mathrm{S})\end{array}$ & $\begin{array}{c}\text { Long. } \\
(\mathrm{E})\end{array}$ & $\begin{array}{c}\text { Elevation } \\
(\mathrm{m} \text { a.s.1. })\end{array}$ & $\begin{array}{c}\text { Distance from } \\
\text { Ross Sea } \\
(\mathrm{km})\end{array}$ & $\begin{array}{c}\text { Distance from } \\
\text { Indian Ocean } \\
(\mathrm{km})\end{array}$ & $\begin{array}{c}\text { Distance to } \\
\text { next core } \\
(\mathrm{km})\end{array}$ \\
\hline $\mathrm{TD}$ & 200 & $72^{\circ} 48^{\prime}$ & $159^{\circ} 06^{\prime}$ & 2315 & 250 & 290 & 71 \\
10 & 200 & $72^{\circ} 12^{\prime}$ & $158^{\circ} 41^{\prime}$ & 2200 & 310 & 240 & 94 \\
9 & 200 & $71^{\circ} 21^{\prime}$ & $158^{\circ} 23^{\prime}$ & 2151 & 380 & 180 & 78 \\
$\mathrm{GV7}$ & 250 & $70^{\circ} 41^{\prime}$ & $158^{\circ} 51^{\prime}$ & 1957 & 430 & 95 & 13 \\
8 & 200 & $70^{\circ} 36^{\prime}$ & $158^{\circ} 35^{\prime}$ & 1934 & 440 & 90 & 11 \\
7 & 200 & $70^{\circ} 31^{\prime}$ & $158^{\circ} 25^{\prime}$ & 1894 & 460 & 90 & 18 \\
6 & 200 & $70^{\circ} 21^{\prime}$ & $158^{\circ} 24^{\prime}$ & 1781 & 470 & 85 & - \\
\hline
\end{tabular}

ments was carried out by repeated measurements of standard samples within the calibration range. The residual standard deviations (RSDs) were respectively $5 \%$ (bromine), $3 \%$ (sodium) and $2 \%$ (iodine).

Procedural UPW blanks were analyzed periodically to test the cleanliness of the instrument lines.

Stable isotopes of water $\left({ }^{18} \mathrm{O}\right.$ and D) measurements were conducted on subsample aliquots, which were immediately refrozen and shipped to the Center for Ice and Climate (Copenhagen, Denmark). Analyses were carried out using a cavity ring-down spectrometer (Picarro, Santa Clara, USA) using the method described by Gkinis et al. (2010). Septumsealed glass vials were used for these measurements to prevent any sample evaporation during the experimental phases.

\section{Results and discussion}

\subsection{Stable water isotopes and snow accumulation}

The cores were dated based on the seasonal variations identified in the stable water isotopes (both $\delta^{18} \mathrm{O}$ and $\delta \mathrm{D}$ ). Midwinters were associated with the relative minima of the isotopic curves (Fig. 2). In case a winter isotopic plateau was found, the center of the plateau was associated to midwinter depth (2011 in core GV7; 2012 and 2011 in core 8; 2010 in core 6$)$. Almost all of the cores cover the period between 2010 and late 2013, providing four years of snow deposition. The only exception is represented by core 6 , whose upper layer is missing.

The annual deposition signal looks less clear in the two cores that were drilled at the sites with the highest elevation and the closest to the Ross Sea, cores TD and 10, and especially for 2013 in core 10 . The two sites are probably the most affected by surface remobilization and isotopic diffusion due to low accumulation. Indeed, nonuniformities in the shallow snow layers such as sastrugi, dunes, wind crusts and other features have been identified as an important aspect of the surface morphology around the Talos Dome area (Frezzotti et al., 2004, 2007).
The annual accumulation rates were calculated by selecting the depth intervals included within consecutive maximum or minimum $\delta^{18} \mathrm{O}$ values (Table 2). Each snow layer within this interval (i.e., sampling resolution, $5 \mathrm{~cm}$ ) was multiplied by the density of the snow at that depth, with the density curves having the same resolution. The contributions were summed over the annual thickness. Table 2 also includes accumulation rates in Victoria Land reported from previous studies. The GV5 site is located between sites 10 and 9 (Fig. 1).

The accumulation rates found during the traverse are in general agreement with the previous works (Becagli et al., 2004b; Frezzotti et al., 2007), except for Talos Dome. The accumulation values calculated from the isotopic profile in Talos Dome are well above those measured by the stake farm ( $n=41$, C. Scarchilli, personal communication, 2016) for the same years. The inconsistency between the accumulation rates derived from the core and those derived from the stake farm and previous measurements suggests that the isotopic assignments of the years may be incorrect at this site and that the profile contains more years than have been assigned. This core is therefore not used in further calculations. The fluxes of deposition of sodium, bromine and iodine in the other cores along the transect are calculated using the accumulation rates from this work.

The accumulation pattern along the transect increases from Talos Dome to the Southern Ocean (GV7, 8, 7 and 6), as the previous works have also found (Magand et al., 2004; Frezzotti et al., 2007). Scarchilli et al. (2011) already pointed out how Talos Dome receives $50 \%$ of its total precipitation from the north-west (Indian Ocean), $30 \%$ from the east (Ross Sea and Pacific Ocean) and approximately $15 \%$ from the interior of the plateau. In this picture, our accumulation data show a decrease from the Indian Ocean to Talos Dome.

The sites are located at decreasing altitudes moving from the Talos Dome site (highest point) towards the coast facing the Indian sector (site 6). The minimum $\delta^{18} \mathrm{O}$ value found in each core shows a decreasing trend with altitude, with an elevation gradient of $-1.35 \%(100 \mathrm{~m})^{-1}$. This super-adiabatic lapse rate is confirmed by the surface snow samples collected during the 2001/02 ITASE traverse (Magand et al., 2004). 


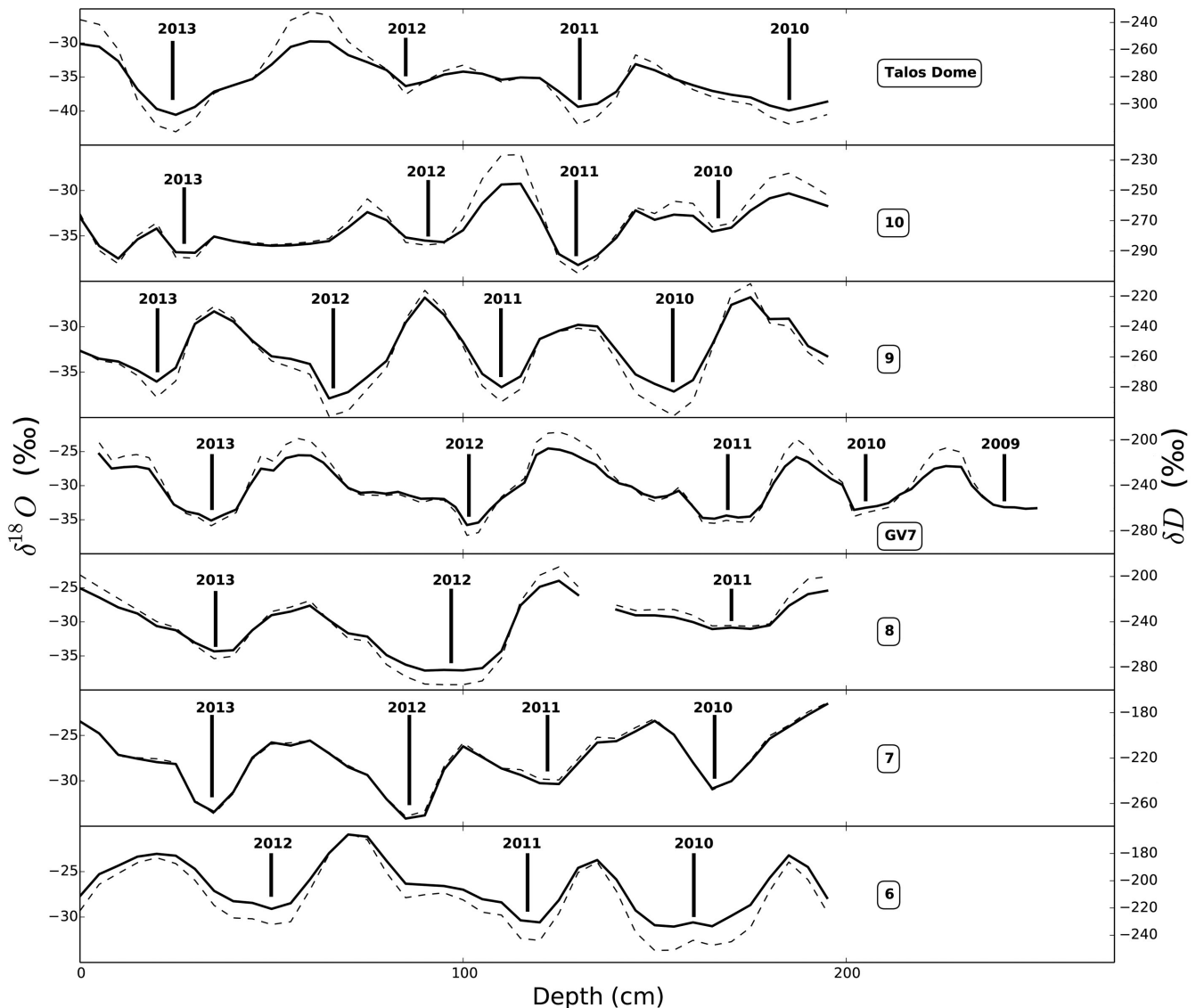

Figure 2. $\delta^{18} \mathrm{O}$ (thick line) and $\delta \mathrm{D}$ (dashed line) profiles of the cores. Resolution of sampling is $5 \mathrm{~cm}$. The winter of each year is indicated with lines in correspondence with the water isotope minima. For core 10, the 2013 winter layer is uncertain.

Table 2. Summary of accumulation rate data from northern Victoria Land. All uncertainties (shown in parentheses) are $1 \sigma$ errors.

\begin{tabular}{|c|c|c|c|c|c|c|c|c|}
\hline \multirow[t]{3}{*}{ Core } & \multicolumn{8}{|c|}{ Accumulation rates $\left(\mathrm{kg} \mathrm{m}^{-2} \mathrm{yr}^{-1}\right)$} \\
\hline & \multicolumn{5}{|c|}{2013 traverse $^{\mathrm{a}}$} & \multirow[t]{2}{*}{$2001-2002^{b}$} & \multirow[t]{2}{*}{$1965-2001^{\mathrm{c}}$} & \multirow[t]{2}{*}{$2001-2012^{\mathrm{d}}$} \\
\hline & 2013 & 2012 & 2011 & 2010 & Average & & & \\
\hline \multirow{2}{*}{$\mathrm{TD}$} & 223 & 144 & 187 & - & $185(31)$ & \multirow{2}{*}{104 (37) } & \multirow{2}{*}{$86.6^{\mathrm{e}}$} & \multirow{2}{*}{$71(4)$} \\
\hline & - & $66^{\mathrm{d}}$ & $107^{\mathrm{d}}$ & $78^{\mathrm{d}}$ & $81(17)^{\mathrm{d}}$ & & & \\
\hline 10 & $260^{\mathrm{f}}$ & 140 & 140 & 120 & $133(9)$ & GV5 $156(27)$ & GV5 $129(6)$ & \\
\hline 9 & 180 & 180 & 180 & 180 & $180(0)$ & & & \\
\hline GV7 & 228 & 261 & 260 & 156 & $232(32)$ & $261(50)$ & $241(12)$ & \\
\hline 8 & 240 & 260 & 280 & - & $260(16)$ & & & \\
\hline 7 & 220 & 180 & 200 & 180 & $195(18)$ & & & \\
\hline 6 & - & 200 & 260 & 200 & $220(29)$ & & & \\
\hline
\end{tabular}

${ }^{\mathrm{a}}$ This work. ${ }^{\mathrm{b}}$ Becagli et al. (2004b). ${ }^{\mathrm{c}}$ Frezzotti et al. (2007). ${ }^{\mathrm{d}}$ From stake farm $(n=41)$ (C. Scarchilli, personal communication, 2016). ${ }^{\mathrm{e}} 1966-1996$ (Stenni et al., 2002). ${ }^{\mathrm{f}}$ Uncertain due to smoothed isotopic signal. 


\subsection{Sodium, Bromine and Iodine}

Sodium shows a mean concentration of $34 \mathrm{ppb}$, in agreement with published values in this area (Becagli et al., 2004a, b; Bertler et al., 2005; Severi et al., 2009). Among the three elements, sodium shows the highest standard deviation (21 ppb) because of the high variability of sea spray inputs at coastal sites. Singularities of up to $200 \mathrm{ppb}$ are probably associated with sea-salt-rich marine storms. Iodine has an average concentration of $43 \mathrm{ppt}$, associated with a lower variability ( $23 \%$ ) compared to bromine (42\%) and sodium (61\%).

The bromine enrichment has been calculated as the bromine excess with respect to seawater concentrations, $\mathrm{Br}_{\text {enr }}=[\mathrm{Br}] /(0.0062 \cdot[\mathrm{Na}])$, where $[\mathrm{Br}]$ and $[\mathrm{Na}]$ are the bromine and sodium concentrations in the sample and 0.0062 is the bromine-to-sodium concentration ratio in seawater (Millero et al., 2008). Similarly, non-sea-salt bromine $[\mathrm{nssBr}]=[\mathrm{Br}]-0.0062 \cdot[\mathrm{Na}]$. Benassai et al. (2005) have concluded that sea-salt sodium is the dominant fraction (more than $80 \%$ ) of the total sodium budget in this area. No correction to sodium was therefore applied for this calculation. Despite bromine being a sea salt marker like sodium, it is activated when gas-phase $\mathrm{HOBr}$ oxidizes bromide over halogen-rich sea ice surfaces (i.e., first-year sea ice, FYSI) and suspended sea salt aerosol and is exponentially released as $\mathrm{Br}_{2}$ (Reaction $\left.\mathrm{R} 4\right)$ :

$\mathrm{HOBr}(\mathrm{g})+\mathrm{HBr}(\mathrm{aq}) \rightarrow \mathrm{Br}_{2}(\mathrm{~g})+\mathrm{H}_{2} \mathrm{O}(\mathrm{aq})$.

Following photolysis, atomic bromine radicals can be converted back to $\mathrm{HBr}$. Therefore, sea ice presence should lead to bromine enrichment or depletion, depending on whether deposition is dominated by the depleted sea salt aerosol or by the enriched gas-phase $\mathrm{HBr}$. Bromine enrichment has already been linked to sea ice presence in both Arctic and Antarctic coastal sites (Simpson et al., 2005; Spolaor et al., 2013b, 2014, 2016; Vallelonga et al., 2017).

The distributions of bromine enrichment values are reported in Fig. 3, divided into the cores closest to the Ross Sea (TD, 10 and 9; blue distribution) and to the Indian Ocean (GV, 8, 7 and 6; red distribution). The first set of cores show on average higher values $(5.7 \pm 0.3)$ than the second $(4.2 \pm 0.2)$. The variability (root mean square, RMS) is also higher $(3.5 \pm 0.2)$ in the first set compared to the "Indian Ocean" set $(2.5 \pm 0.1)$ because of greater distance covered by the sampling ( $165 \mathrm{~km}$ compared to $40 \mathrm{~km})$. Overall, the values extend from a minimum of $0.5-17$ with more than $98 \%$ of the samples showing values greater than 1 (i.e., seawater enriched values). A detailed insight into the few $<1$ values revealed that these samples were associated with very high contributions of sodium inputs ( $>120 \mathrm{ppb}$ ) and therefore likely associated with strong marine events. Such distribution of enrichment supports the theory that this parameter is, in these coastal sites, affected by sea ice signature.

The measurements of the chemical species for the different coring sites along the traverse are reported in Figs. 4-6

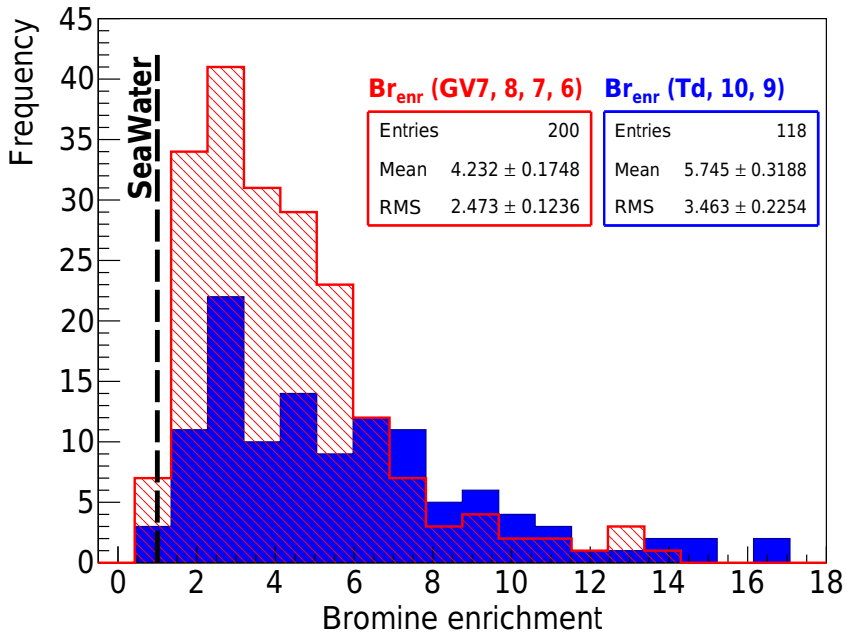

Figure 3. Distribution of bromine enrichment values within cores TD, 10 and 9 (blue) and GV7, 8, 7 and 6 (red). The dashed line indicates the seawater value $\left(\mathrm{Br}_{\mathrm{enr}}=1\right)$.

on an age scale (with the exception of Talos Dome which is reported on a depth scale in the supplementary material). Sodium time series show great variability: peaks are often found in summer, although they are also observed in winter, e.g., in core 8 . These findings confirm that, as previous works pointed out (Curran et al., 1998), in coastal sites, storm events carrying open ocean sea salts are more important than sea ice as a sea salt source, although the high level of variability also suggests that meteorology and natural variability play a role (Wagenbach et al., 1998). Bromine and both $\mathrm{Br}_{\mathrm{enr}}$ and $\mathrm{nssBr}$ show annual variations, with maximum values in late spring-summer, confirming ice core measurements by Spolaor et al. (2014), Vallelonga et al. (2017) and aerosol measurements by Legrand et al. (2016). Iodine shows a more stable signal throughout the year, although a high winter singularity and a more extended peak are observed in the GV7 and 8 cores respectively.

The timing of the bromine enrichment signal in ice cores relies on the combined effect of sea ice and sunlight responsible for the photochemical production and release of molecular bromine, $\mathrm{Br}_{2}$ (Pratt et al., 2013). Sea ice area in the $130^{\circ} \mathrm{E}-170^{\circ} \mathrm{W}$ sector was calculated for the $2010-2013$ period using publicly available NSIDC passive microwave sea ice concentration data (Meier et al., 2013) by multiplying the sea concentration in each grid pixel by the area of the pixel $\left(25 \times 25 \mathrm{~km}^{2}\right)$ and integrating over the domain. The longitude sector was decided on the basis of Scarchilli et al. (2011), who concluded that air masses arriving in this area originate from the Ross Sea and from the Indian Ocean sector by analyzing 5-day back trajectories from 1980 to 2001. Figure 1b shows the minimum and maximum found in January 2010 and August 2011, respectively. The monthly sea ice areas from 2010 to 2013 were calculated for such sector and plotted in Fig. 7a (blue); each monthly value was normalized to 

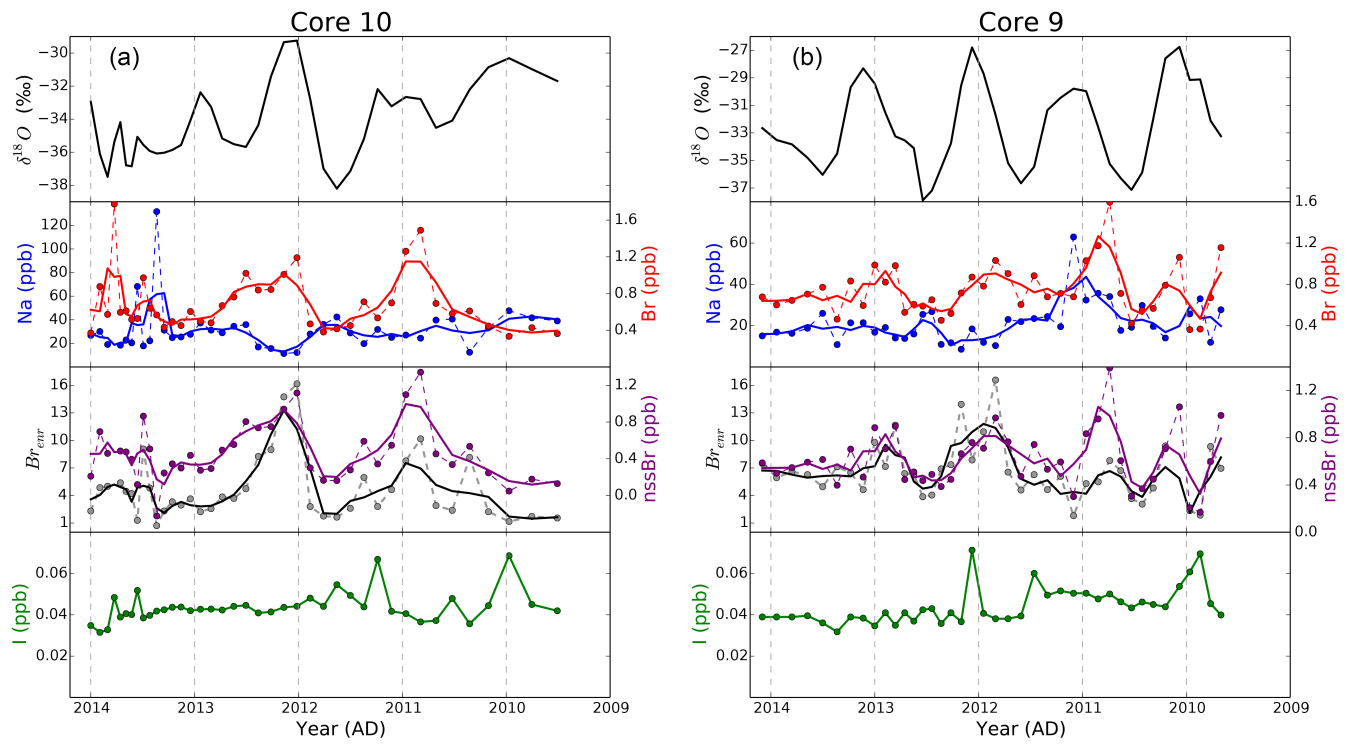

Figure 4. Variability of $\delta^{18} \mathrm{O}$ (upper panel), $\mathrm{Na}$ (middle top panel, left axis), Br (middle top panel, right axis), Brenr (middle bottom panel, left axis), nssBr (middle bottom panel, right axis) and I (bottom panel) in cores 10 (left) and 9 (right). Thick lines represent 3-month running means of the raw data (circles).
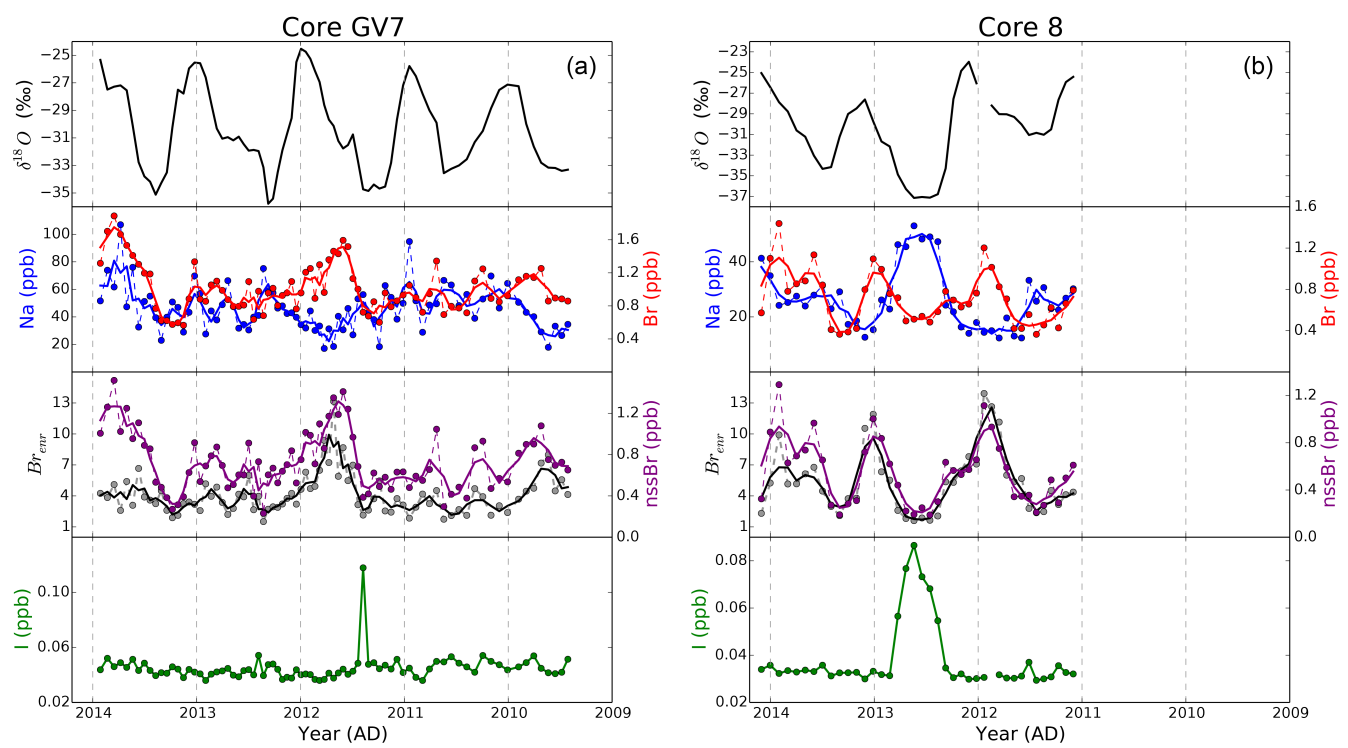

Figure 5. Variability of $\delta^{18} \mathrm{O}$ (upper panel), $\mathrm{Na}$ (middle top panel, left axis), Br (middle top panel, right axis), Brenr (middle bottom panel, left axis), nssBr (middle bottom panel, right axis) and I (bottom panel) in cores GV7 (left) and 8 (right). Thick lines represent 3-month running means of the raw data (circles).

the total annual sea ice area. The minimum sea ice is found in February, while a longer-lasting maximum throughout winter and spring is observed, before a rapid decrease in November. Solar radiation values Fig. 7a (red points) were calculated at $71^{\circ} \mathrm{S}, 158^{\circ} \mathrm{E}$ using the tropospheric ultraviolet and visible (TUV) radiation model within the $[300,500] \mathrm{nm}$ wavelength interval. Each point represents a daily average of the 15 th day of each month of 2012 and is considered a monthly representation.
The sub-annual distribution of bromine enrichment along the transect is shown in Fig. 7b (blue). Each bin contains the cumulative monthly value for every year in every core normalized by the total value of each year (which may change according to year and location). The histogram is then normalized by the overall sum measured in the transect. The distribution shows a clear sub-annual oscillation with lowest and highest annual contribution in May (autumn) and OctoberNovember (late spring), respectively. The combined effect of 

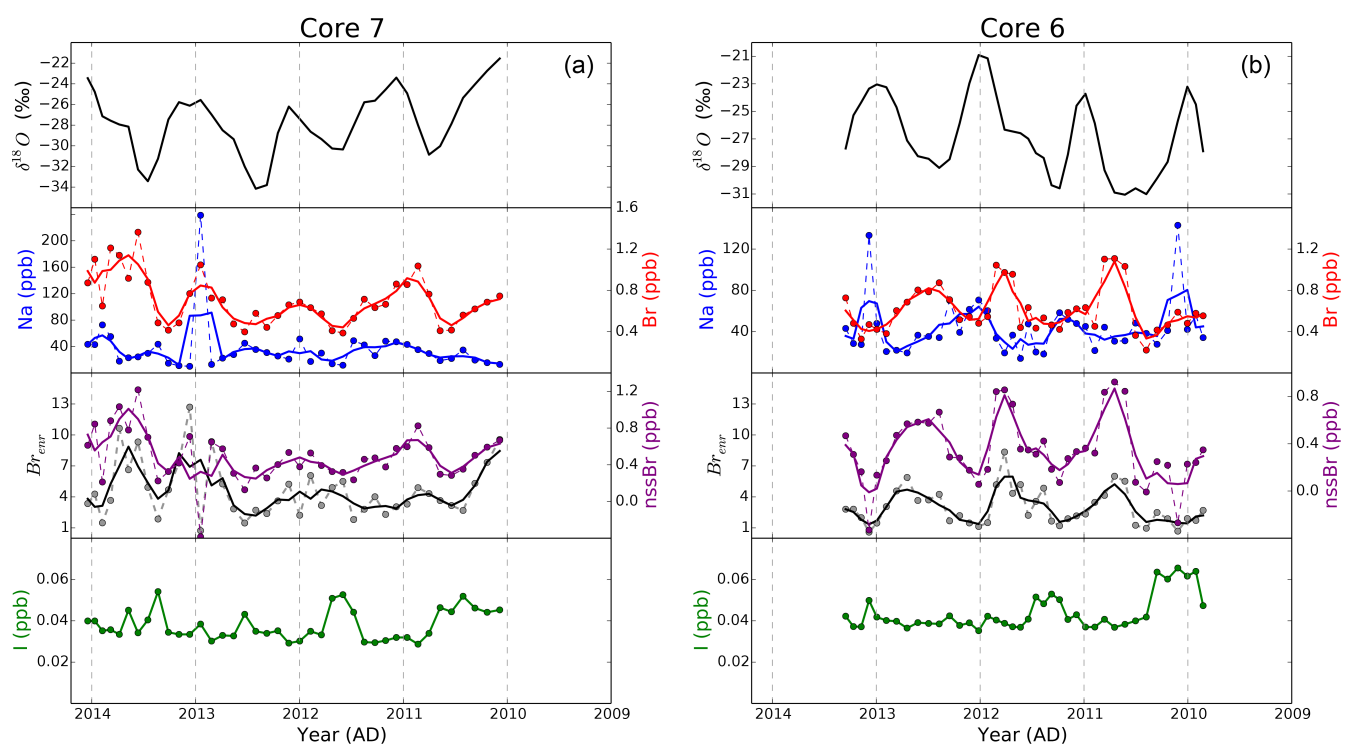

Figure 6. Variability of $\delta^{18} \mathrm{O}$ (upper panel), $\mathrm{Na}$ (middle top panel, left axis), Br (middle top panel, right axis), Brenr (middle bottom panel, left axis), nssBr (middle bottom panel, right axis) and I (bottom panel) in cores 7 (left) and 6 (right). Thick lines represent 3-month running means of the raw data (circles).

Table 3. Iodine average concentrations and variability during the 2013-2010 time period. All values are expressed in ppb.

\begin{tabular}{|c|c|c|c|c|c|c|c|c|}
\hline \multirow[t]{2}{*}{ Core } & \multicolumn{2}{|c|}{2013} & \multicolumn{2}{|c|}{2012} & \multicolumn{2}{|c|}{2011} & \multicolumn{2}{|c|}{2010} \\
\hline & I & SD & I & SD & I & SD & I & SD \\
\hline 10 & 0.041 & 0.005 & 0.043 & 0.001 & 0.049 & 0.008 & 0.040 & 0.005 \\
\hline 9 & 0.038 & 0.003 & 0.041 & 0.010 & 0.046 & 0.008 & 0.047 & 0.003 \\
\hline GV7 & 0.044 & 0.004 & 0.042 & 0.004 & 0.043 & 0.004 & 0.047 & 0.005 \\
\hline 8 & 0.033 & 0.002 & 0.049 & 0.021 & 0.032 & 0.002 & - & - \\
\hline 7 & 0.038 & 0.006 & 0.034 & 0.004 & 0.037 & 0.009 & 0.041 & 0.008 \\
\hline 6 & - & - & 0.039 & 0.002 & 0.044 & 0.006 & 0.041 & 0.008 \\
\hline
\end{tabular}

sea ice and insolation (Fig. 7b, magenta product distribution) shows similar features, with the maximum in November, albeit with a much more pronounced springtime increase than is seen in the bromine enrichment. Such comparison suggests that the combined effect of sea ice and insolation is related to the seasonality of bromine enrichment. Monthly sea ice area values are reported in Fig. 7c (blue) together with annual averaged values of bromine enrichment (black) and first-year sea ice (red), calculated as the difference of maximum and minimum sea ice areas. A longer record would be needed to evaluate the correlation between bromine enrichment values and FYSI area and investigate a quantitative link.

Table 3 shows the average annual iodine concentrations for each location together with its standard deviation. The mean value $(0.043 \mathrm{ppb})$ is close to the background values found in Antarctic shallow firn cores near the research stations of Neumayer (Frieß et al., 2010) and Casey (Law Dome, Spolaor et al., 2014). Unlike previous observations of a clear winter peak of iodine with concentrations up to $0.6 \mathrm{ppb}$ (Neumayer) and $0.3 \mathrm{ppb}$ (Law Dome), no clear seasonality is observed in the transect records, with annual variability around 10-15\%. Core 7 (Fig. 6) shows some variability which corresponds to winter peaks. High iodine concentrations are observed in core 8 during the 2012 winter, in association with a strong sea salt (sodium) input, although similar strong winter peaks are observed in 2011 at GV7.

The low background level and low variability of iodine found along the transect reflect a low input of iodine in this area of Antarctica compared to other locations. This picture is confirmed by satellite measurements, which show average IO concentrations close to the detection limit over the area of the transect compared to Law Dome, Neumayer or any other coastal location (Fig. 8, right panel). The high elevation of the traverse area, compared to the others, is likely to play a role in preventing efficient iodine transport from the source areas.

Frieß et al. (2010) and Spolaor et al. (2014) have attributed iodine seasonal signal patterns to summertime photochem- 

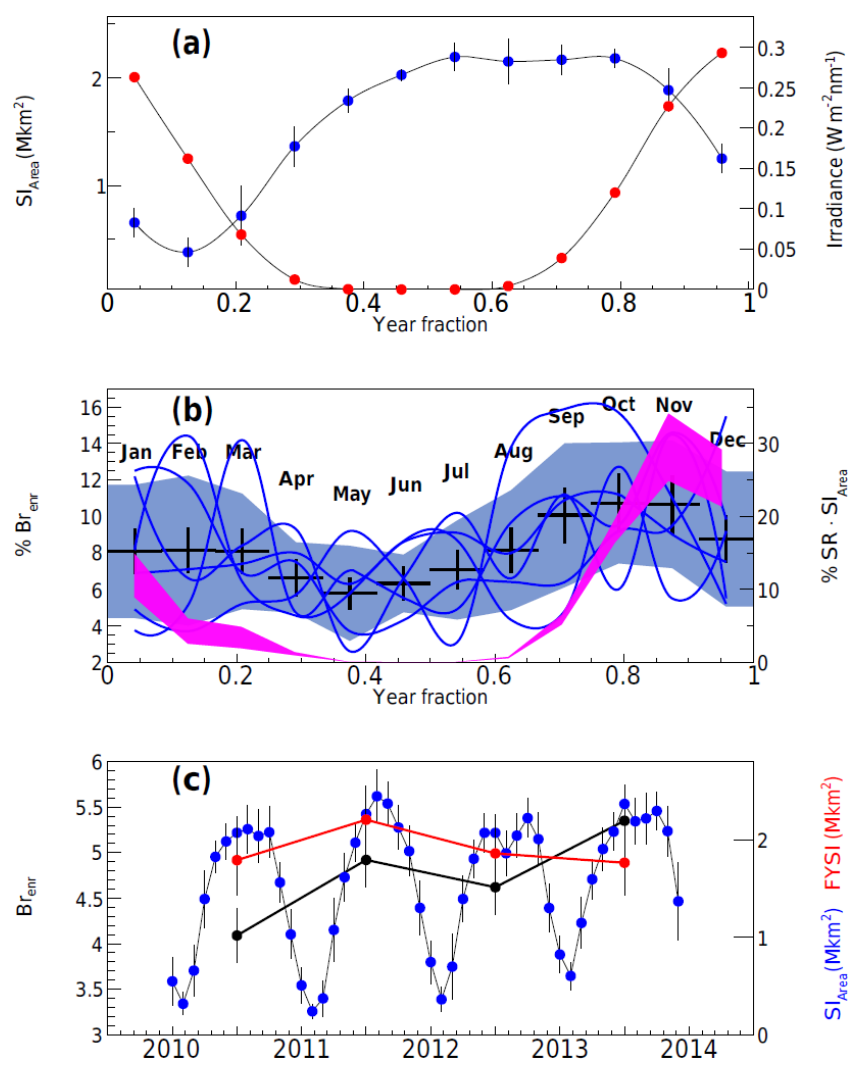

Figure 7. (a) Monthly values of sea ice area (blue) within the $130^{\circ} \mathrm{E}-170^{\circ} \mathrm{W}$ sector from 2010 to $2013( \pm 1 \sigma$, month variability) and daily average $(24 \mathrm{~h})$ total downwelling spectral irradiance (red) calculated using the TUV model at $71^{\circ} \mathrm{S}, 158^{\circ} \mathrm{E}$. Each irradiance calculation was set on the 15 th day of each month in 2012 . (b) Seasonality of annual bromine enrichment along the traverse: the monthly trend shows a seasonal feature with the maximum in spring. Each line refers to a core of the transect $( \pm 1 \sigma$, shaded blue area). The month averages are displayed in black. The systematic uncertainties associated with the dating are shown as verticals error bars. The magenta band represents the product distribution of normalized sea ice area and insolation expressed in annual percentage. (c) Monthly sea ice area values (blue) from 2010 to 2013 with annual values of FYSI (red) and averaged bromine enrichment (black).

ical recycling of IO from the snowpack, leading to depletion in the summer layers and higher concentrations in winter when absence of sunlight inhibits photoactivation. The lower variability found across the northern Victoria Land traverse cores could result from a reduced summer recycling due to low iodine concentrations available in the snow.

\subsection{Spatial flux variability}

Glaciochemistry around Antarctica is very strongly influenced by, among several properties, the distance from the sea and the pathways of the air mass trajectories (Bertler et al., 2005). Atmospheric circulation patterns around the Talos Dome area have been investigated by Scarchilli et al. (2011),
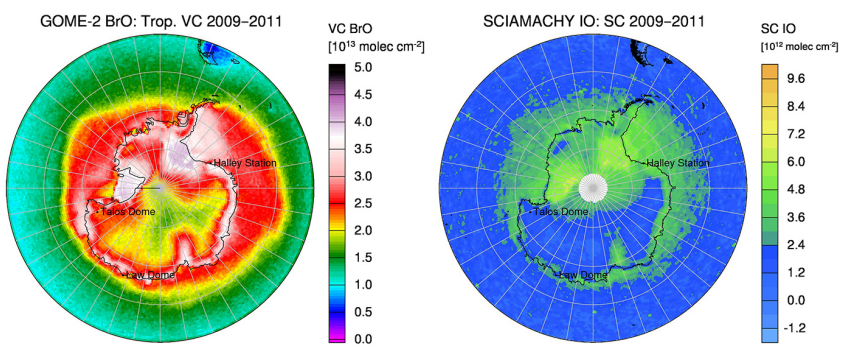

Figure 8. Average atmospheric column concentrations of $\mathrm{BrO}$ and IO in Antarctica between 2009 and 2011 from Spolaor et al. (2014).

who have shown that the main input is represented by the Southern Ocean (Indian sector) with a lower contribution from the Ross Sea.

The spatial variability of sodium, bromine, bromine enrichment and iodine is investigated in Fig. 9. The twelve panels display the annual fluxes of $\mathrm{Na}, \mathrm{Br}$, I and integrated annual values of bromine enrichment for each core in relation to its distance from the Indian Ocean. Sodium fluxes show the highest values and variability around the closest locations to the Southern Ocean (GV7, 8, 7 and 6), where the accumulation increases. After rapidly decreasing within the first $100 \mathrm{~km}$, the sodium flux becomes stable as the input from the SO decreases but the one from the Ross Sea gradually increases. Bromine exhibits a similar behavior to sodium with a homogeneous flux within cores 10 and 9 and an increase (up to 3 times) in the last $100 \mathrm{~km}$ from the SO. Elevation could partly account for the fractionation of sodium and bromine, having $180 \mathrm{~m}$ of height difference separating GV7, 8, 7 and 6, and $240 \mathrm{~m}$ from GV7 to core 10 . The effect of elevation is combined with the influence of the distance from the source to resolve the two effects. The pattern of bromine enrichment is linked among other things to the different bromine fractionations during transport in the gas phase and the aerosol phase compared to sodium. Unlike sodium and bromine, no decrease is observed for bromine enrichment from our data (Fig. 9, second column), although no clear trend can be inferred. This can be due to the multiple origins of air advection (Ross Sea/Indian Ocean) to their uneven strength or because the distances are not large enough for any difference to be observed.

A slightly lower fractionation after $100 \mathrm{~km}$ from the $\mathrm{SO}$ is observed for iodine, consistent with the homogeneous satellite measurements of IO (Fig. 9, right).

\section{Conclusions}

The 2013/14 Talos Dome - GV7 traverse provided an opportunity to expand the existing sodium dataset in Victoria Land and investigate important features of bromine and iodine temporal and spatial variabilities so far only available in Antarctica at Law Dome and Neumayer station. 

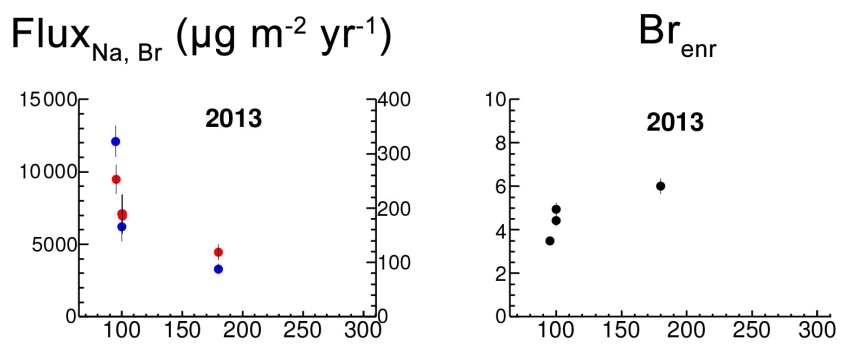

$\operatorname{Flux}_{\text {iodine }}\left(\mu \mathrm{g} \mathrm{m}^{-2} \mathrm{yr}^{-1}\right)$
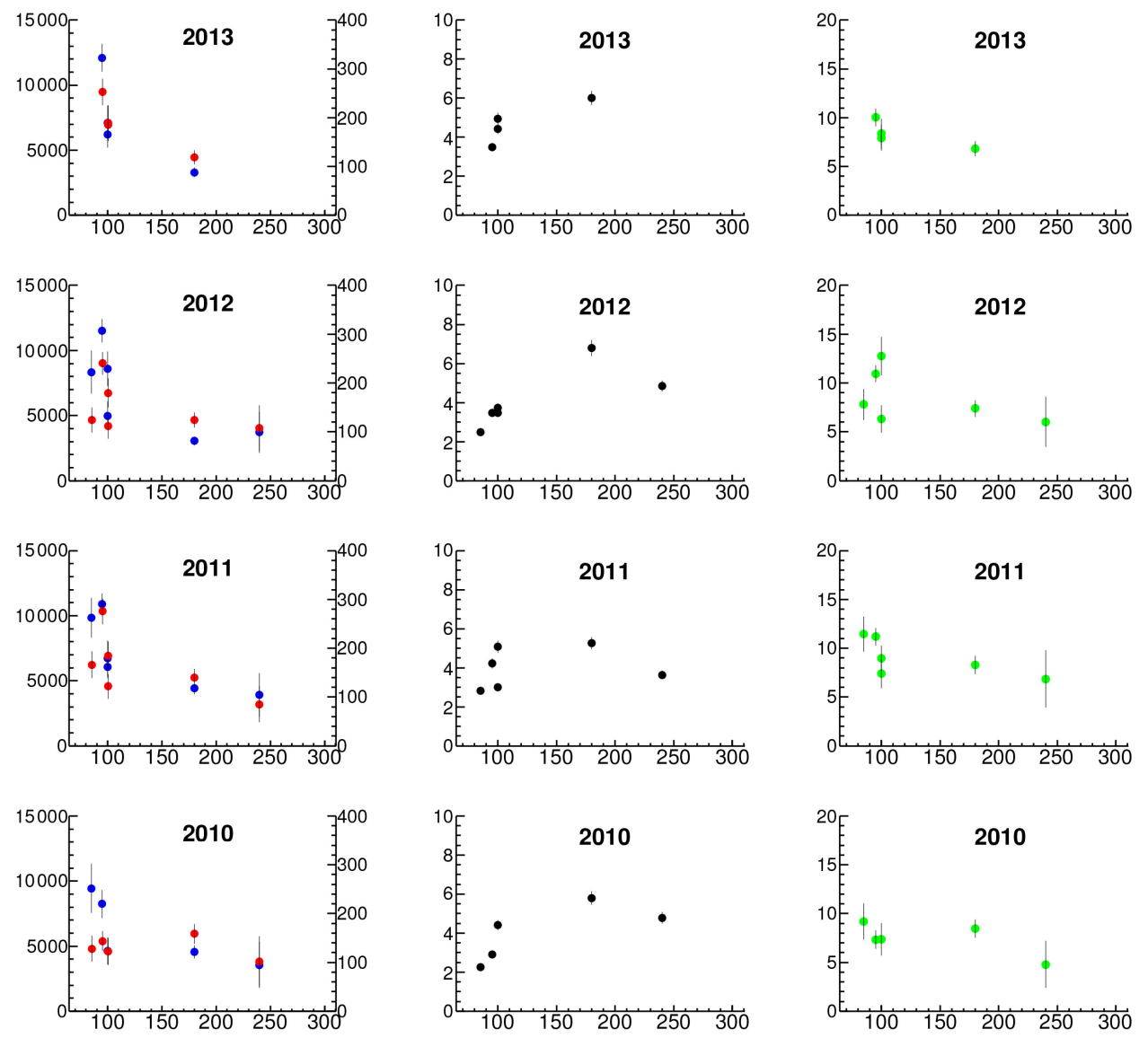

\section{Distance from Indian Ocean (km)}

Figure 9. Mean annual fluxes of sodium (blue, left axes), bromine (red, right axes), iodine (green) and bromine enrichment values (black) as a function of distance from the Indian Ocean. Each dot represents a location along the traverse.

The accumulation rates agree with previous studies, with increasing values from the Ross Sea to the Southern Ocean. Accumulation rates calculated at Talos Dome are higher than previously reported, likely caused by isotopic diffusion and remobilization. Further studies are required at this site in order to access the reproducibility of the climate signal. The locations near the Southern Ocean exhibit high variability due to the higher accumulation.

Sodium and bromine concentrations in the snow samples result in a positive bromine enrichment compared to seawater, confirming the sea ice influence in the area for the extra bromine deposition. While sodium does not capture clear sub-annual variations associated with sea ice, bromine enrichment shows consistent seasonal variabilities with late spring maxima. There is some evidence that the seasonality is linked to the combined effect of sea ice growth and sunlight, which trigger photochemistry above fresh sea ice. The timing of deposition is coherent among Victoria Land, Law Dome, Dumont d'Urville (Indian sector) and Neumayer (Atlantic sector). Iodine shows an average value of $0.04 \mathrm{ppb}$, similar to background values observed in the Antarctic coastal locations of Law Dome and Neumayer. Unlike those locations, low iodine annual variability and no consistent seasonality of the signal are observed in the traverse samples.

The spatial variability study reveals homogeneous fluxes of $\mathrm{Na}, \mathrm{Br}$ and I over the transect length, with an increase in absolute values and variability at the sites close to the Indian Ocean due to high accumulation and proximity to the coasts. Uniform satellite values of $\mathrm{BrO}$ and IO over Victoria Land are consistent with the snow measurements. A fractionation due to distance of these potential proxies is probably not found due to the combined double input of air masses from the Ross Sea and the Indian Ocean.

A transect covering larger distances and directed towards the interior of the plateau would give an insight into this feature, especially clarifying the spatial pattern of bromine enrichment with respect to the differences in gas-phase and aerosol depositions. 
Data availability. Data are publicly available online through the PANGAEA data repository (https://doi.pangaea.de/10.1594/ PANGAEA.873041).

\section{The Supplement related to this article is available online at doi:10.5194/tc-11-693-2017-supplement.}

Competing interests. The authors declare that they have no conflict of interest.

Acknowledgements. We thank the scientists who conducted the traverse and provided the samples, the chemistry group in Venice for the chemical measurements and the isotope laboratory in Copenhagen for the measurements of the water isotopes. We also thank Rasmus Anker Pedersen and Emilie Capron for the useful suggestions and comments.

This research was carried out in the framework of the Project on Glaciology and Paleoclimatology of the Italian PNRA National Antarctic Program.

The research leading to these results has received funding from the European Research Council under the European Community's Seventh Framework Programme (FP7/2007-2013)/ERC grant agreement 610055 as part of the ice 2 ice project.

Edited by: J. Savarino

Reviewed by: three anonymous referees

\section{References}

Abbatt, J. P. D., Thomas, J. L., Abrahamsson, K., Boxe, C., Granfors, A., Jones, A. E., King, M. D., Saiz-Lopez, A., Shepson, P. B., Sodeau, J., Toohey, D. W., Toubin, C., von Glasow, R., Wren, S. N., and Yang, X.: Halogen activation via interactions with environmental ice and snow in the polar lower troposphere and other regions, Atmos. Chem. Phys., 12, 6237-6271, doi:10.5194/acp-12-6237-2012, 2012.

Abram, N. J., Curran, M. A. J., Mulvaney, R., and Vance, T.: The preservation of methanesulphonic acid in frozen ice-core samples, J. Glaciol., 54, 680-684, doi:10.3189/002214308786570890, 2008.

Abram, N. J., Thomas, E. R., McConnell, J. R., Mulvaney, R., Bracegirdle, T. J., Sime, L. C., and Aristarain, A. J.: Ice core evidence for a 20th century decline of sea ice in the Bellingshausen Sea, Antarctica, J. Geophys. Res., 115, D23101, doi:10.1029/2010JD014644, 2010.

Abram, N. J., Wolff, E. W., and Curran, M. A. J.: A review of sea ice proxy information from polar ice cores, Quaternary Sci. Rev., 79, 168-183, doi:10.1016/j.quascirev.2013.01.011, 2013.

Adams, J. W., Holmes, N. S., and Crowley, J. N.: Uptake and reaction of $\mathrm{HOBr}$ on frozen and dry $\mathrm{NaCl} / \mathrm{NaBr}$ surfaces between 253 and 233 K, Atmos. Chem. Phys., 2, 79-91, doi:10.5194/acp2-79-2002, 2002.

Atkinson, H. M., Huang, R.-J., Chance, R., Roscoe, H. K., Hughes, C., Davison, B., Schönhardt, A., Mahajan, A. S., Saiz-Lopez, A., Hoffmann, T., and Liss, P. S.: Iodine emissions from the sea ice of the Weddell Sea, Atmos. Chem. Phys., 12, 11229-11244, doi:10.5194/acp-12-11229-2012, 2012.

Barrie, L. A., Bottenheim, J. W., Schnell, R. C., Crutzen, P. J., and Rasmussen, R. A.: Ozone destruction and photochemical reactions at polar sunrise in the lower Arctic atmosphere, Nature, 334, 138-141, doi:10.1038/334138a0, 1988.

Becagli, S., Benassai, S., Castellano, E., Largiuni, O., Migliori, A., Traversi, R., Flora, O., and Udisti, R.: Chemical characterization of the last 250 years of snow deposition at Talos Dome (East Antarctica), Int. J. Environ. An. Ch., 84, 523-536, doi:10.1080/03067310310001640384, 2004a.

Becagli, S., Proposito, M., Benassai, S., Flora, O., Genoni, L., Gragnani, R., Largiuni, O., Pili, S. L., Severi, M., Stenni, B., Traversi, R., Udisti, R., and Frezzotti, M.: Chemical and isotopic snow variability in East Antarctica along the 2001/02 ITASE traverse, Ann. Glaciol., 39, 473-482, doi:10.3189/172756404781814636, 2004b.

Becagli, S., Proposito, M., Benassai, S., Gragnani, R., Magand, O., Traversi, R., and Udisti, R.: Spatial distribution of biogenic sulphur compounds (MSA, nssSO ${ }_{4}^{2}$ ) in the northern Victoria Land - Dome C - Wilkes Land area, East Antarctica, Ann. Glaciol., 23-31, doi:10.3189/172756405781813384, 2005.

Bertler, N., Mayewski, P. A., Aristarain, A., Barrett, P., Becagli, S., Bernardo, R., Bo, S., Xiao, C., Curran, M., Qin, D., Dixon, D. A., Ferron, F., Fischer, H., Frey, M., Frezzotti, M., Fundel, F., Genthon, C., Gragnani, R., Hamilton, G. S., Handley, M., Hong, S., Isaksson, E., Kang, J., Ren, J., Kamiyama, K., Kanamori, S., Kärkäs, E., Karlöf, L., Kaspari, S., Kreutz, K., Kurbatov, A., Meyerson, E., Ming, Y., Zhang, M., Motoyama, H., Mulvaney, R., Oerter, H., Osterberg, E., Proposito, M., Pyne, A., Ruth, U., Simões, J., Smith, B., Sneed, S., Teinilä, K., Traufetter, F., Udisti, R., Virkkula, A., Watanabe, O., Williamson, B., Winther, J. G., Li, Y., Wolff, E., Li, Z., and Zielinski, A.: Snow chemistry across Antarctica, Ann. Glaciol., 41, 167-179, doi:10.3189/172756405781813320, 2005.

Curran, M. A. J., Van Ommen, T. D., and Morgan, V.: Seasonal characteristics of the major ions in the high-accumulation Dome Summit South ice core, Law Dome, Antarctica, Ann. Glaciol., 27, 385-390, doi:10.3198/1998AoG27-1-385-390, 1998.

Curran, M. A. J., van Ommen, T. D., Morgan, V. I., Phillips, K. L., and Palmer, A. S.: Ice Core Evidence for Antarctic Sea Ice Decline Since the1950s, Science, 302, 1203-1206, doi:10.1126/science.1087888, 2003.

Delmas, B. R. J., Wagnon, P., Kamiyama, K., and Watanabe, O.: Evidence for the loss of snow-deposited MSA to the interstitial gaseous phase in central Antarctic firn, Tellus B, 55, 71-79, doi:10.1034/j.1600-0889.2003.00032.x, 2003.

Frezzotti, M., Bitelli, G., De Michelis, P., Deponti, A., Forieri, A., Gandolfi, S., Maggi, V., Mancini, F., Remy, F., Tabacco, I. E., Urbini, S., Vittuari, L., and Zirizzottl, A.: Geophysical survey at Talos Dome, East Antarctica: The search for a new deep-drilling site, Ann. Glaciol., 39, 423-432, doi:10.3189/172756404781814591, 2004.

Frezzotti, M., Urbini, S., Proposito, M., Scarchilli, C., and Gandolfi, S.: Spatial and temporal variability of surface mass balance near Talos Dome, East Antarctica, J. Geophys. Res., 112, F02032, doi:10.1029/2006JF000638, 2007. 
Frieß, U., Deutschmann, T., Gilfedder, B. S., Weller, R., and Platt, U.: Iodine monoxide in the Antarctic snowpack, Atmos. Chem. Phys., 10, 2439-2456, doi:10.5194/acp-10-2439-2010, 2010.

Gkinis, V., Popp, T. J., Johnsen, S. J., and Blunier, T.: A continuous stream flash evaporator for the calibration of an IR cavity ring-down spectrometer for the isotopic analysis of water, Isot. Environ. Healt. S., 46, 463-475, doi:10.1080/10256016.2010.538052, 2010.

Grilli, R., Legrand, M., Kukui, A., Méjean, G., Preunkert, S., and Romanini, D.: First investigations of $\mathrm{IO}, \mathrm{BrO}$, and $\mathrm{NO}_{2}$ summer atmospheric levels at a coastal East Antarctic site using modelocked cavity enhanced absorption spectroscopy, Geophys. Res. Lett., 40, 791-796, doi:10.1002/grl.50154, 2013.

Grootes, P. M., Steig, E. J., Stuiver, M., Waddington, E. D., Morse, D. L., and Nadeau, M.-J.: The Taylor Dome Antarctic ${ }^{18} \mathrm{O}$ Record and Globally Synchronous Changes in Climate, Quaternary Res., 56, 289-298, doi:10.1006/qres.2001.2276, 2001.

Isaksson, E., Kekonen, T., Moore, J., and Mulvaney, R.: The methanesulfonic acid (MSA) record in a Svalbard ice core, Ann. Glaciol., 42, 345-351, doi:10.3189/172756405781812637, 2005.

Legrand, M., Yang, X., Preunkert, S., and Theys, N.: Year-round records of sea salt, gaseous, and particulate inorganic bromine in the atmospheric boundary layer at coastal (Dumont d'Urville) and central (Concordia) East Antarctic sites, J. Geophys. Res.Atmos., 121, 997-1023, doi:10.1002/2015JD024066, 2016.

Magand, O., Frezzotti, M., Pourchet, M., Stenni, B., Genoni, L., and Fily, M.: Climate variability along latitudinal and longitudinal transects in East Antarctica, Ann. Glaciol., 39, 351-358, doi:10.3189/172756404781813961, 2004.

Mahajan, A. S., Shaw, M., Oetjen, H., Hornsby, K. E., Carpenter, L. J., Kaleschke, L., Tian-Kunze, X., Lee, J. D., Moller, S. J., Edwards, P., Commane, R., Ingham, T., Heard, D. E., and Plane, J. M. C.: Evidence of reactive iodine chemistry in the Arctic boundary layer, J. Geophys. Res., 115, D20303, doi:10.1029/2009JD013665, 2010.

Maselli, O. J., Chellman, N. J., Grieman, M., Layman, L., McConnell, J. R., Pasteris, D., Rhodes, R. H., Saltzman, E., and Sigl, M.: Sea ice and pollution-modulated changes in Greenland ice core methanesulfonate and bromine, Clim. Past, 13, 39-59, doi:10.5194/cp-13-39-2017, 2017.

Mayewski, P. A., Frezzotti, M., Bertler, N., Van Ommen T., Hamilton, G., Jacka, T. H., Welch, B., Frey, M., Dahe, Q., Jiawen, R., Simöes, J., Fily, M., Oerter, H., Nishio, F., Isaksson, E., Mulvaney, R., Holmund, P., Lipenkov, V., and Goodwin, I.: The International Trans-Antarctic Scientific Expedition (ITASE): An overview, Ann. Glaciol., 41, 180-185, doi:10.3189/172756405781813159, 2005.

Meier, W., Fetterer, F., Savoie, M., Mallory, S., Duerr, R., and Stroeve, J.: NOAA/NSIDC Climate Data Record of Passive Microwave Sea Ice Concentration, Version 2, National Snow and Ice Data Center (NSIDC), Boulder, Colorado, USA, doi:10.7265/N55M63M1, last access: 5 September 2016, updated 2015, 2013.

Millero, F. J., Feistel, R., Wright, D. G., and McDougall, T. J.: The composition of Standard Seawater and the definition of the Reference-Composition Salinity Scale, Deep-Sea Res. Pt. I, 55, 50-72, doi:10.1016/j.dsr.2007.10.001, 2008.
Mulvaney, R., Pasteur, E. C., Peel, D. A., Saltzman, E. S., and Whung, P.-Y.: The ratio of MSA to non-sea-salt sulphate in Antarctic Peninsula ice cores, Tellus B, 44, 295-303, doi:10.1034/j.1600-0889.1992.t01-2-00007.x, 1992.

Pasteur, E. C. and Mulvaney, R.: Migration of methane sulphonate in Antarctic firn and ice, J. Geophys. Res., 105, 11525-11534, doi:10.1029/2000JD900006, 2000.

Pratt, K. A., Custard, K. D., Shepson, P. B., Douglas, T. A., Pöhler, D., General, S., Zielcke, J., Simpson, W. R., Platt, U., Tanner, D. J., Gregory Huey, L., Carlsen, M., and Stirm, B. H.: Photochemical production of molecular bromine in Arctic surface snowpacks, Nat. Geosci., 6, 351-356, doi:10.1038/ngeo1779, 2013.

Preunkert, S., Legrand, M., Jourdin, B., Moulin, C., Belviso, S., Kasamatsu, N., Fukuchi, M., and Hirawake, T.: Interannual variability of dimethylsulfide in air and seawater and its atmospheric oxidation by-products (methanesulfonate and sulfate) at Dumont d'Urville, coastal Antarctica (1999-2003), J. Geophys. Res., 112, D06306, doi:10.1029/2006JD007585, 2007.

Proposito, M., Becagli, S., Castellano, E., Flora, O., Genoni, L., Gragnani, R., Stenni, B., Traversi, R., Udisti, R., and Frezzotti, M.: Chemical and isotopic snow variability along the 1998 ITASE traverse from Terra Nova Bay to Dome C, East Antarctica, Ann. Glaciol., 35, 187-194, doi:10.3189/172756402781817167, 2002.

Saiz-Lopez, A., Mahajan, A. S., Salmon, R. A., Bauguitte, S. J.B., Jones, A. E., Roscoe, H. K., and Plane, J. M. C.: Boundary Layer Halogens in Coastal Antarctica, Science, 317, 348-351, doi:10.1126/science.1141408, 2007.

Saiz-Lopez, A., Plane, J. M. C., Baker, A. R., Carpenter, L. J., von Glasow, R., Gómez Martín, J. C., McFiggans, G., and Saunders, R. W.: Atmospheric Chemistry of Iodine, Chem. Rev., 112, 1773-1804, doi:10.1021/cr200029u, 2012a.

Saiz-Lopez, A. and von Glasow, R.: Reactive halogen chemistry in the troposphere, Chem. Soc. Rev., 41, 6448, doi:10.1039/c2cs35208g, 2012b.

Sala, M., Delmonte, B., Frezzotti, M., Proposito, M., Scarchilli, C., Maggi, V., Artioli, G., Dapiaggi, M., Marino, F., Ricci, P. C., and De Giudici, G.: Evidence of calcium carbonates in coastal (Talos Dome and Ross Sea area) East Antarctica snow and firn: Environmental and climatic implications, Earth Planet. Sc. Lett., 271, 43-52, doi:10.1016/j.eps1.2008.03.045, 2008.

Sander, R., Keene, W. C., Pszenny, A. A. P., Arimoto, R., Ayers, G. P., Baboukas, E., Cainey, J. M., Crutzen, P. J., Duce, R. A., Hönninger, G., Huebert, B. J., Maenhaut, W., Mihalopoulos, N., Turekian, V. C., and Van Dingenen, R.: Inorganic bromine in the marine boundary layer: a critical review, Atmos. Chem. Phys., 3, 1301-1336, doi:10.5194/acp-3-1301-2003, 2003.

Scarchilli, C., Frezzotti, M., and Ruti, P. M.: Snow precipitation at four ice core sites in East Antarctica: Provenance, seasonality and blocking factors, Clim. Dynam., 37, 2107-2125, doi:10.1007/s00382-010-0946-4, 2011.

Schönhardt, A., Richter, A., Wittrock, F., Kirk, H., Oetjen, H., Roscoe, H. K., and Burrows, J. P.: Observations of iodine monoxide columns from satellite, Atmos. Chem. Phys., 8, 637-653, doi:10.5194/acp-8-637-2008, 2008.

Schönhardt, A., Begoin, M., Richter, A., Wittrock, F., Kaleschke, L., Gómez Martín, J. C., and Burrows, J. P.: Simultaneous satel- 
lite observations of $\mathrm{IO}$ and $\mathrm{BrO}$ over Antarctica, Atmos. Chem. Phys., 12, 6565-6580, doi:10.5194/acp-12-6565-2012, 2012.

Severi, M., Becagli, S., Castellano, E., Morganti, A., Traversi, R., and Udisti, R.: Thirty years of snow deposition at Talos Dome (Northern Victoria Land, East Antarctica): Chemical profiles and climatic implications, Microchem. J., 92, 15-20, doi:10.1016/j.microc.2008.08.004, 2009.

Simpson, W. R., Alvarez-Aviles, L., Douglas, T. A., Sturm, M., and Domine, F.: Halogens in the coastal snow pack near Barrow, Alaska: Evidence for active bromine air-snow chemistry during springtime, Geophys. Res. Lett., 32, L04811, doi:10.1029/2004GL021748, 2005.

Simpson, W. R., von Glasow, R., Riedel, K., Anderson, P., Ariya, P., Bottenheim, J., Burrows, J., Carpenter, L. J., Frieß, U., Goodsite, M. E., Heard, D., Hutterli, M., Jacobi, H.-W., Kaleschke, L., Neff, B., Plane, J., Platt, U., Richter, A., Roscoe, H., Sander, R., Shepson, P., Sodeau, J., Steffen, A., Wagner, T., and Wolff, E.: Halogens and their role in polar boundary-layer ozone depletion, Atmos. Chem. Phys., 7, 4375-4418, doi:10.5194/acp-74375-2007, 2007.

Spolaor, A., Gabrieli, J., Martma, T., Kohler, J., Björkman, M. B., Isaksson, E., Varin, C., Vallelonga, P., Plane, J. M. C., and Barbante, C.: Sea ice dynamics influence halogen deposition to Svalbard, The Cryosphere, 7, 1645-1658, doi:10.5194/tc-7-16452013, 2013a.

Spolaor, A., Vallelonga, P., Plane, J. M. C., Kehrwald, N., Gabrieli, J., Varin, C., Turetta, C., Cozzi, G., Kumar, R., Boutron, C., and Barbante, C.: Halogen species record Antarctic sea ice extent over glacial-interglacial periods, Atmos. Chem. Phys., 13, 66236635, doi:10.5194/acp-13-6623-2013, 2013 b.

Spolaor, A., Vallelonga, P., Gabrieli, J., Martma, T., Björkman, M. P., Isaksson, E., Cozzi, G., Turetta, C., Kjær, H. A., Curran, M. A. J., Moy, A. D., Schönhardt, A., Blechschmidt, A.-M., Burrows, J. P., Plane, J. M. C., and Barbante, C.: Seasonality of halogen deposition in polar snow and ice, Atmos. Chem. Phys., 14, 9613-9622, doi:10.5194/acp-14-9613-2014, 2014.

Spolaor, A., Opel, T., McConnell, J. R., Maselli, O. J., Spreen, G., Varin, C., Kirchgeorg, T., Fritzsche, D., Saiz-Lopez, A., and Vallelonga, P.: Halogen-based reconstruction of Russian Arctic sea ice area from the Akademii Nauk ice core (Severnaya Zemlya), The Cryosphere, 10, 245-256, doi:10.5194/tc-10-2452016, 2016a.

Spolaor, A., Vallelonga, P., Turetta, C., Maffezzoli, N., Cozzi, G., Gabrieli, J., Barbante, C., Goto-Azuma, K., Saiz-Lopez, A., Cuevas, C. A., and Dahl-Jensen, D.: Canadian Arctic sea ice reconstructed from bromine in the Greenland NEEM ice core, Scientific Reports, 6, 33925, doi:10.1038/srep33925, 2016 b.

Stenni, B., Proposito, M., Gragnani, R., Flora, O., Jouzel, J., Falourd, S., and Frezzotti, M.: Eight centuries of volcanic signal and climate change at Talos Dome (East Antarctica), J. Geophys. Res., 107, ACL 3-1-ACL 3-13, doi:10.1029/2000JD000317, 2002.

Stenni, B., Buiron, D., Frezzotti, M., Albani, S., Barbante, C., Bard, E., Barnola, J. M., Baroni, M., Baumgartner, M., Bonazza, M., Capron, E., Castellano, E., Chappellaz, J., Delmonte, B., Falourd, S., Genoni, L., Iacumin, P., Jouzel, J., Kipfstuhl, S., Landais, a., Lemieux-Dudon, B., Maggi, V., Masson-Delmotte, V., Mazzola, C., Minster, B., Montagnat, M., Mulvaney, R., Narcisi, B., Oerter, H., Parrenin, F., Petit, J. R., Ritz, C., Scarchilli, C., Schilt,
A., Schüpbach, S., Schwander, J., Selmo, E., Severi, M., Stocker, T. F., and Udisti, R.: Expression of the bipolar see-saw in Antarctic climate records during the last deglaciation, Nat. Geosci., 3, 1-4, doi:10.1038/ngeo1026, 2011.

Thomas, J. L., Stutz, J., Lefer, B., Huey, L. G., Toyota, K., Dibb, J. E., and von Glasow, R.: Modeling chemistry in and above snow at Summit, Greenland - Part 1: Model description and results, Atmos. Chem. Phys., 11, 4899-4914, doi:10.5194/acp-11-48992011, 2011.

Vallelonga, P., Maffezzoli, N., Moy, A. D., Curran, M. A. J., Vance, T. R., Edwards, R., Hughes, G., Barker, E., Spreen, G., Saiz-Lopez, A., Corella, J. P., Cuevas, C. A., and Spolaor, A.: Sea-ice-related halogen enrichment at Law Dome, coastal East Antarctica, Clim. Past, 13, 171-184, doi:10.5194/cp-13171-2017, 2017.

Vogt, R., Crutzen, P. J., and Sander, R.: A mechanism for halogen release from sea-salt aerosol in the remote marine boundary layer, Nature, 383, 327-330, doi:10.1038/383327a0, 1996.

Wagenbach, D., Ducroz, F., Mulvaney, R., Keck, L., Minikin, A., Legrand, M., Hall, J. S., and Wolff, E. W.: Sea-salt aerosol in coastal Antarctic regions, J. Geophys. Res., 103, 10961, doi:10.1029/97JD01804, 1998.

Weller, R., Traufetter, F., Fischer, H., Oerter, H., Piel, C., and Miller, H.: Postdepositional losses of methane sulfonate, nitrate, and chloride at the European Project for Ice Coring in Antarctica deep-drilling site in Dronning Maud Land, Antarctica, J. Geophys. Res., 109, D07301, doi:10.1029/2003JD004189, 2004.

Weller, R., Wagenbach, D., Legrand, M., Elsässer, C., TianKunze, X. and König-Langlo, G.: Continuous 25-yr aerosol records at coastal Antarctica - I: Inter-annual variability of ionic compounds links to climate indices, Tellus B, 63, 901-919, doi:10.1111/j.1600-0889.2011.00542.x, 2011.

Wolff, E. W., Fischer, H., Fundel, F., Ruth, U., Twarloh, B., Littot, G. C., Mulvaney, R., Röthlisberger, R., de Angelis, M., Boutron, C. F., Hansson, M., Jonsell, U., Hutterli, M. A., Lambert, F., Kaufmann, P., Stauffer, B., Stocker, T. F., Steffensen, J. P., Bigler, M., Siggaard-Andersen, M. L., Udisti, R., Becagli, S., Castellano, E., Severi, M., Wagenbach, D., Barbante, C., Gabrielli, P., and Gaspari, V.: Southern Ocean sea-ice extent, productivity and iron flux over the past eight glacial cycles, Nature, 440, 491-496, doi:10.1038/nature06271, 2006.

Yang, X., Cox, R. A., Warwick, N. J., Pyle, J. A., Carver, G. D., O'Connor, F. M., and Savage, N. H.: Tropospheric bromine chemistry and its impacts on ozone: A model study, J. Geophys Res., 110, D23311, doi:10.1029/2005JD006244, 2005.

Yang, X., Pyle, J. A., and Cox, R. A.: Sea salt aerosol production and bromine release: Role of snow on sea ice, Geophys. Res. Lett., 35, L16815, doi:10.1029/2008GL034536, 2008. 